\title{
Estrogen receptor-dependent and independent roles of benzo[a]pyrene in Ishikawa cells
}

\author{
Isabelle Lee', Guannan Zhang1,2, Clementina Mesaros ${ }^{1,2}$ and Trevor M Penning $[1,2$ \\ 1Department of Systems Pharmacology \& Translational Therapeutics, Perelman School of Medicine, University of Philadelphia, Philadelphia, \\ Pennsylvania, USA \\ ${ }^{2}$ Center of Excellence in Environmental Toxicology, Perelman School of Medicine, University of Philadelphia, Philadelphia, Pennsylvania, USA
}

Correspondence should be addressed to T M Penning: penning@upenn.edu

\begin{abstract}
Polycyclic aromatic hydrocarbons (PAHs) are environmental pollutants generated from the incomplete combustion of organic material. PAHs have been studied as genotoxicants, but some also act via non-genotoxic mechanisms in estrogen-dependent malignancies, such as breast cancer. PAHs require metabolic activation to electrophilic metabolites to exert their genotoxicity but non-genotoxic properties may also contribute to their carcinogenicity. The role of PAHs in endometrial cancer, a cancer associated with unopposed estrogen action is unknown. We assessed the metabolism of the representative $\mathrm{PAH}$, benzo[ $[a]$ pyrene $(\mathrm{B}[a] \mathrm{P})$, to estrogenic compounds in Ishikawa human endometrial cells in the presence and absence of cytochrome P450 induction. Using stable-isotope dilution high-performance liquid chromatography and APCI tandem mass spectrometry in the selected reaction monitoring mode, we analyzed $\mathrm{B}[a] \mathrm{P}$ metabolism in Ishikawa cells. Estrogenic activity of $\mathrm{B}[a] \mathrm{P}$ metabolites was determined by the endogenous estrogen inducible alkaline phosphatase reporter gene and an exogenous estrogen response element (ERE) luciferase reporter gene construct. We also assessed whether PAHs can induce a proliferative phenotype via estrogen receptor (ER)- and non-ER-regulated pathways. We demonstrate that $\mathrm{B}[a] \mathrm{P}$ can be metabolized in human endometrial cells into $3-\mathrm{OH}-\mathrm{B}[a] \mathrm{P}$ and $\mathrm{B}[a] \mathrm{P}-7,8$-dione in sufficient amounts to activate ERs. We also show that only $\mathrm{B}[a] \mathrm{P}-7,8$-dione induces endometrial cell proliferation at concentrations lower than required to activate the ER; instead nongenomic signaling by the EGF receptor (EGFR) and activation of the mitogen-activated protein kinase (MAPK) pathway was responsible. This work indicates that human endometrial cells can metabolize PAHs into estrogenic metabolites, which may induce cell proliferation through non-ER-regulated pathways.
\end{abstract}
Key Words
- benzo[a]pyrene
- metabolism
- estrogen receptor
- Ishikawa
- endometrium

Journal of Endocrinology (2020) 247, 139-151

\section{Introduction}

Polycyclic aromatic hydrocarbons (PAHs) are pervasive environmental toxicants and the representative compound, benzo $[a]$ pyrene $(\mathrm{B}[a] \mathrm{P})$, is ranked as a Group 1 carcinogen by the International Agency for Research on Cancer (IARC) (Korsh et al. 2015). Ambient PAHs are released primarily from the incomplete combustion of fossil fuels and motor vehicular traffic; however, oral uptake of PAHs may also occur via consumption of smoked and grilled meat and fish, while dermal exposure to PAHs may result from the use of consumer products that 
contain black rubber (Armstrong et al. 2004, Korsh et al. 2015). PAHs have been implicated in divergent estrogen signaling mechanisms (Santodonato 1997, Hayakawa et al. 2011, Lam et al. 2018) in laboratory rodent models (Hirose et al. 2001, Kummer et al. 2008, Borek-Dohalska et al. 2016) and in in vitro human cell line models (Gozgit et al. 2004, Pliskova et al. 2005), suggesting that they can be added to the growing list of endocrine-disrupting chemicals.

PAHs have been implicated in estrogen receptordependent cancers. Women had a twofold increased risk of breast cancer associated with detectable levels of PAH relative to women with non-detectable levels, and this association increased with higher levels of PAHs rising to a level of absolute breast cancer risk (10-year risk $\geq 3.4 \%$ : $\mathrm{OR}=4.09,95 \% \mathrm{CI}=1.38-12.13$ ) (Shen et al. 2017). PAHs have been extensively used to experimentally induce breast carcinogenesis (Morris \& Seifter 1992). PAHs have been implicated in cancer initiation (including breast cancer) via the induction of DNA damage, through the formation of DNA adducts in target tissues (Kriek et al. 1993, Rundle et al. 2000, Gammon et al. 2002). However, $\mathrm{PAH}$ has also been linked to cancer promotion by cell proliferation via estrogen receptor (ER)-mediated signaling (Santodonato 1997). Two PAHs, benz[a]anthracene $(\mathrm{B}[a] \mathrm{A})$ and $\mathrm{B}[a] \mathrm{P}$, have been shown to stimulate the proliferation of human breast carcinoma MCF-7 cells via an ER-dependent mechanism, and this proliferation was blocked by the antiestrogen, ICI 182,780 (Plíšková et al. 2005). These data suggest that the proliferative effects of PAHs could contribute to tumor promotion in estrogensensitive tissues via the ER.

While there is ample evidence for genotoxic and nongenotoxic estrogenic signaling in breast cancer models, the role of PAHs in the development of other ER-dependent cancers such as endometrial cancer still needs clarification. Endometrial cancer is the most common malignancy within the female reproductive system (Siegel et al. 2019). Most endometrial malignancies are driven by aberrant hormone signaling, where estrogen signal transduction through estrogen receptor alpha (ER $\alpha)$ functions as an oncogenic signal (Rutledge 1976, Rodriguez et al. 2019).

PAHs have been marginally linked to endometrial cancer. Consumption of 101-200 g of red meat per day raises a woman's risk to endometrial cancer development by 2 -fold, and this was attributed to the formation of heterocyclic amines and/or PAHs during the processing of meat at high temperatures (PlagensRotman et al. 2016). Additionally, a Taiwanese 30-year population-based epidemiological study showed an increase in endometrial cancer with increasing air pollutants, such as $\mathrm{B}[a] \mathrm{P}$ (Huang et al. 2012). In the immature rat uterotrophic assay in Wistar rats, PAHs including $\mathrm{B}[a] \mathrm{P}, \mathrm{B}[a] \mathrm{A}$ or fluoranthene administered consecutively for 3 days at $10 \mathrm{mg} / \mathrm{kg} /$ day led to a significant increase of uterine weight and hypertrophy of the luminal epithelium, suggesting that they behaved as estrogen-like compounds (Kummer et al. 2008). These effects were likely facilitated by $\mathrm{ER} \alpha$, the predominant ER isoform in the uterus (Brandenberger et al. 1999), as they were abrogated by the ER antagonist, ICI 182,780. Non-ER-regulated pathways such as the EGF receptor (EGFR) (Tu et al. 2011) and/or mitogen-activated protein kinase (MAPK) (Zhou et al. 2011) pathways have also been implicated in estrogen signaling in endometrial cancer. PAHs have similarly been implicated in EGFR and MAPK pathways in their role in cancer development (Burdick et al. 2003, Rodríguez-Fragoso et al. 2009, Song et al. 2013). This evidence suggests that PAHs may play a role in endometrial cancer development via estrogen receptor and non-estrogen receptor pathways. However, there is a dearth of studies that assess PAH metabolism in endometrial cancer and the estrogenic properties of the metabolites that may form.

PAHs require metabolic activation to highly reactive electrophiles to exert their carcinogenicity (Shimada \& Fujii-Kuriyama 2004). Cytochrome P450s (P450s) are implicated in the metabolism of PAHs and are inducible by PAHs and polyhalogenated hydrocarbons (such as 2,3,7,8-tetrachlorodibenzo[b,e][1,4]-dioxin (TCDD)), via the aryl hydrocarbon receptor (AhR) (Poland et al. 1976, Sanderson et al. 2001, Schaufler et al. 2002). It is thus important to conduct metabolism studies with and without TCDD induction.

In this study, we used Ishikawa endometrial cells to represent type 1 endometriod adenocarcinoma cells, which respond to stimulation by unopposed estrogens. We tested the hypothesis that $\mathrm{B}[a] \mathrm{P}$ metabolism is induced in these cells with TCDD to yield estrogenic compounds using stable-isotope dilution highperformance liquid chromatography and APCI mass spectrometry. We tested whether the metabolites formed induced an endogenous alkaline phosphatase reporter gene and an estrogen response element (ERE) luciferase reporter gene construct as read-outs of ER activation. We also investigated whether $\mathrm{B}[a] \mathrm{P}$ metabolites can induce a proliferative phenotype via ER- and non-ERregulated pathways. https://joe.bioscientifica.com https://doi.org/10.1530/JOE-19-0579
(C) 2020 Society for Endocrinology Published by Bioscientifica Ltd. Printed in Great Britain 


\section{Materials and methods}

Hazardous agents used in this work were handled in accordance with the NIH Guidelines for the Laboratory Use of Chemical Carcinogens.

\section{Reagents and chemicals}

The unlabeled $\mathrm{B}[\mathrm{a}] \mathrm{P}$ metabolite standards were purchased from the NCI Chemical Carcinogen Standard Reference Repository (Midwest Research Institute, Kansas City, $\mathrm{MO}, \mathrm{USA})$. The $\left[{ }^{13} \mathrm{C}_{4}\right]$-labeled $\mathrm{B}[\mathrm{a}] \mathrm{P}$ metabolite internal standards were synthesized as described (Ran et al. 2008). The identities and purity of all the standards were established by LC-MS and HPLC, as previously published (Lu et al. 2011). All solvents were of HPLC grade, and all other chemicals were of the highest purity available and were used without further purification. Cell culture media were obtained from Invitrogen Co. except for fetal bovine serum (FBS), which was from Hyclone Laboratories (Logan, UT, USA). p-Nitrophenyl phosphate (pNPP) was obtained from Sigma Aldrich, and the dual-luciferase reporter assay system was obtained from Promega.

\section{Cell culture}

Transformed human endometrial cells, Ishikawa cells, were obtained from Sigma Aldrich (99040201-1VL) and maintained in MEM $+2 \mathrm{mM}$ glutamine $+1 \%$ non-essential amino acids (NEAA) +5\% fetal bovine serum (FBS), 100 units/mL penicillin, and $100 \mu \mathrm{g} / \mathrm{mL}$ streptomycin. All cells were maintained in $10^{2} \mathrm{~cm}$ dishes and were incubated at $37^{\circ} \mathrm{C}$ in a humidified incubator maintained at $5 \% \mathrm{CO}_{2}$, and culture media were renewed every $2-3$ days. The cells were subcultured every 4-5 days using 0.25\% trypsin. Cultured cells with a passage number of 6-16 were used to reduce variability. Before each experiment, the cells were seeded in phenol red-free DMEM/F12 with 5\% charcoal dextran stripped (CDS) FBS (estrogen depleted media) for $48 \mathrm{~h}$.

\section{Liquid chromatography tandem-mass spectrometric analysis}

We reported a reversed-phase HPLC method, which separated all the major $\mathrm{B}[a] \mathrm{P}$ metabolites over $60 \mathrm{~min}$ (Lu et al. 2011). To optimize shorter run times, we injected $\mathrm{B}[\mathrm{a}] \mathrm{P}$ metabolite standards individually as well as a mixture onto a Kinetex XB Biphenyl 100 x $2.1 \mathrm{~mm}$ 2.6 $\mu \mathrm{m}$ column (Phenomenex, Torrance, CA, USA).
Satisfactory chromatographic separation of $\mathrm{B}[\mathrm{a}] \mathrm{P}$ metabolites was obtained using $5 \mathrm{mM}$ ammonium acetate in water plus $0.02 \%(\mathrm{v} / \mathrm{v})$ formic acid as mobile phase A and $5 \mathrm{mM}$ ammonium acetate in acetonitrile plus $0.02 \%$ $(\mathrm{v} / \mathrm{v})$ formic acid as mobile phase $\mathrm{B}$. This mobile phase is compatible with LC-MS analysis due to the volatility of ammonium acetate. All B[a]P standards (200 pmol) of interest were well separated in a 25 min gradient.

A Finnigan TSQ Quantum Ultra spectrometer (Thermo Fisher) interfaced with a Waters Alliance 2690 HPLC system (Waters Corporation, Milford, MA, USA) was used for the LC-MS/MS analyses. Chromatographic separation for the LC-MS/MS analyses was achieved with the Kinetex XB Biphenyl column. The eluent from the HPLC column was directly introduced into a standard atmospheric pressure chemical ionization (APCI) source equipped with a corona discharge pin. Nitrogen was used as the nebulizing gas as well as the sheath gas and auxiliary gas. The vaporizer and capillary temperatures were set at 400 and $270^{\circ} \mathrm{C}$, respectively. All the hydroxylated standards under positive APCI conditions were predominated by stable dehydrated precursors, expected from s-phase dehydration that results in loss of $\mathrm{H}_{2} \mathrm{O}$, which were chosen as parent ions in SRM analysis. B[a]P-7,8-transdihydrodiol formed a $\left[\mathrm{M}+\mathrm{H}-\mathrm{H}_{2} \mathrm{O}\right]+$ parent ion $m / z 269$ and a $\left[\mathrm{M}+\mathrm{H}-2 \mathrm{H}_{2} \mathrm{O}\right]^{+}$product ion $\mathrm{m} / \mathrm{z}$ 251; while $3-\mathrm{OH}-\mathrm{B}[\mathrm{a}] \mathrm{P}$ generated the $[\mathrm{M}+\mathrm{H}]^{+}$parent ion $m / z 269$ which lost a molecule of water $\left[\mathrm{M}+\mathrm{H}-\mathrm{H}_{2} \mathrm{O}\right]+$ to give a product ion $m / z$ 251; $\mathrm{B}[a] \mathrm{P}-7,8$-dione formed a $[\mathrm{M}+\mathrm{H}]^{+}$parent ion $m / z 283$ and a product ion $[\mathrm{M}+\mathrm{H}-\mathrm{CO}]+m / z \quad 255$; and $\mathrm{B}[\mathrm{a}] \mathrm{P}$-tetraol gave a $\left[\mathrm{M}+\mathrm{H}-2 \mathrm{H}_{2} \mathrm{O}\right]$ as a parent ion of $\mathrm{m} / \mathrm{z}$ 285 and a product ion of $\left[\mathrm{M}+\mathrm{H}-3 \mathrm{H}_{2} \mathrm{O}-\mathrm{CO}\right]$ of $m / z 239$. By contrast $\mathrm{B}[a] \mathrm{P}$ did not fragment and gave a parent ion of $[\mathrm{M}+\mathrm{H}]^{+} \mathrm{m} / \mathrm{z} 253$ only. The metabolites measured were therefore detected under the following SRM transitions: $m / z \quad 269 \quad\left[\mathrm{M}+\mathrm{H}-\mathrm{H}_{2} \mathrm{O}\right]^{+} \rightarrow m / z \quad 251 \quad\left[\mathrm{M}+\mathrm{H}-2 \mathrm{H}_{2} \mathrm{O}\right]^{+}$for $\mathrm{B}[a] \mathrm{P}-7,8$-trans-dihydrodiol; $m / z \quad 269 \quad[\mathrm{M}+\mathrm{H}]^{+} \rightarrow$ $m / z 251\left[\mathrm{M}+\mathrm{H}-\mathrm{H}_{2} \mathrm{O}\right]+$ for $3-\mathrm{OH}-\mathrm{B}[a] \mathrm{P} ; m / z 283[\mathrm{M}+\mathrm{H}]+\rightarrow$ $m / z \quad 255 \quad[\mathrm{M}+\mathrm{H}-\mathrm{CO}]^{+}$for $\mathrm{B}[a] \mathrm{P}-7,8$-dione; $m / z \quad 285$ $\left[\mathrm{M}+\mathrm{H}-2 \mathrm{H}_{2} \mathrm{O}\right] \rightarrow m / z \quad 239 \quad\left[\mathrm{M}+\mathrm{H}-3 \mathrm{H}_{2} \mathrm{O}-\mathrm{CO}\right]$ for $\mathrm{B}[a] \mathrm{P}$-tetraol; and $m / z 253[\mathrm{M}+\mathrm{H}]+$ for $\mathrm{B}[a] \mathrm{P}$.

To generate the calibration curves, $\sim 100$ pmol of $\left[{ }^{13} \mathrm{C}_{4}\right]$-internal standards $(\mathrm{B}[\mathrm{a}] \mathrm{P}, \mathrm{B}[\mathrm{a}] \mathrm{P}-7,8$-transdihydrodiol, 3-OH-B $[a] \mathrm{P}$ and $\mathrm{B}[a] \mathrm{P}-7,8$-dione) were spiked with different nmol amounts of the unlabeled $\mathrm{B}[\mathrm{a}] \mathrm{P}$ and its metabolites $(0,0.3125,0.625,1.25,2.5,5$ and 10$)$ in a $150 \mu \mathrm{L}$ volume. The HPLC method described previously was used, and the flow rate was set at $0.3 \mathrm{~mL} / \mathrm{min}$. The peak area ratios of the analyte $/\left[{ }^{13} \mathrm{C}_{4}\right]$-internal standard were plotted against the concentrations of analytes. 
The linearity of the calibration curves was considered satisfactory in the studied range of concentrations ( $R^{2}>0.99$ for all $\mathrm{B}[a] \mathrm{P}$ standards). The isotopically labeled $\mathrm{B}[a] \mathrm{P}$ metabolite internal standards co-eluted with the unlabeled standards and gave $m / z$ values that were 4 amu higher.

\section{$\mathrm{B}[a] \mathrm{P}$ metabolism in Ishikawa cells}

The metabolism of $\mathrm{B}[a] \mathrm{P}$ in Ishikawa cells was conducted according to published procedures (Lu et al. 2011). Briefly, the cells $\left(\sim 3 \times 10^{6}\right)$ were induced with TCDD $(10 \mathrm{nM})$ in $2 \mathrm{~mL}$ of charcoal dextran stripped FBS MEM medium for $24 \mathrm{~h}$ before $\mathrm{B}[a] \mathrm{P}$ treatment $(5 \mu \mathrm{M}, 0.1 \% \mathrm{DMSO})$ in $2 \mathrm{~mL}$ of HBSS (10 mM glucose). Control experiments were performed in a similar manner with the exception that DMSO was substituted for TCDD. Cells were sampled at $0,3,6,12$, and $24 \mathrm{~h}$. The $2 \mathrm{~mL}$ media was siphoned into a $5 \mathrm{~mL}$ tube, after which $2 \mathrm{~mL}$ of fresh media was added to cells then harvested by a cell scraper into a $5 \mathrm{~mL}$ tube and the media and cells extracted twice with $3 \mathrm{~mL}$ of water-saturated ethyl acetate. Before extraction, a $\left[{ }^{13} \mathrm{C}_{4}\right]-\mathrm{B}[\mathrm{a}] \mathrm{P}$ metabolite standard cocktail (containing $\sim 100$ pmol analytes of each analyte) was added to each sample to normalize for losses in the sample workup and analysis. The organic extract was dried under vacuum, and the residue was dissolved in $150 \mu \mathrm{L}$ of $90 \%$ methanol and put into an autosampler vial for LC-MS/MS analysis. All incubations were performed in triplicate in three independent experiments.

\section{Alkaline phosphatase activity assay}

Ishikawa cells were seeded at a density of $5 \times 10^{4}$ cells in 96-well plates. Media was replaced with media containing $5 \%$ charcoal dextran stripped FBS and no phenol-red. They were treated with ethinyl estradiol (EE), or with the appropriate $\mathrm{B}[a] \mathrm{P}$ metabolite in a dose-dependent manner, and after $48 \mathrm{~h}$ media was removed and lysis buffer $(0.1 \mathrm{M}$ Tris/HCL, $0.1 \%$ Triton X, $100 \mathrm{mM}$ glycine, $1 \mathrm{nM} \mathrm{MgCl}, 1 \mathrm{mM} \mathrm{ZnCl}, \mathrm{pH} 9.8$ ) added and transferred to $-80^{\circ} \mathrm{C}$ for $12 \mathrm{~h}$ before measuring alkaline phosphatase activity. Alkaline phosphatase activity was assayed by monitoring the hydrolysis of $p$-nitrophenyl phosphate (pNPP) to p-nitrophenol at $\mathrm{pH} 9.8$ and measuring the formation of the $p$-nitrophenolate anion at $405 \mathrm{~nm}$ (molar extinction coefficient $=18,000 / \mathrm{M}^{-1} \mathrm{~cm}^{-1}$ ). Calibration curves were generated with p-nitrophenol under alkaline conditions, so that absorbance could be converted to pmoles (Littlefield et al. 1990).
Experiments were first conducted by increasing the concentration of either $\mathrm{EE}$ or $\mathrm{B}[a] \mathrm{P}$ metabolite. The assays were repeated in the presence of $5 \mu \mathrm{M} \quad \mathrm{B}[a] \mathrm{P}$ metabolites (predetermined) or $1 \mathrm{nM}$ EE and a dose-dependent inhibition with fulvestrant (Sigma Aldrich), an estrogen receptor antagonist, was measured. All experiments were reproduced in three independent experiments. Curves were fitted to non-linear regression models in Prism version 7.00 for Windows (GraphPad Software).

\section{Transient transfection and dual-luciferase activity assay}

Ishikawa cells were seeded at a density of $2 \times 10^{4}$ cells in 96-well plates. The cells were transfected with the pERE-luciferase plasmid, which contains three copies of the Xenopus laevis vitellogenin A2 ERE upstream of the firefly luciferase reporter. To normalize for transfection efficiency a pRL-TK plasmid, which contains a cDNA encoding Renilla luciferase, was co-transfected. Co-transfection was conducted using $0.4 \mu \mathrm{g}$ of pEREluciferase plasmid and $2.5 \mathrm{ng}$ of pRL-TK plasmid with $0.5 \mu \mathrm{L}$ of lipofectamine 2000 reagent (Invitrogen). Transfection solutions were replaced after $24 \mathrm{~h}$, and cells were treated with $\mathrm{EE}$, or with the appropriate $\mathrm{B}[a] \mathrm{P}$ metabolite in a dose-dependent manner. Cells were treated for $24 \mathrm{~h}$ prior to cell lysis and measurement of firefly- and Renilla luciferase luminescence using the Stop-Glo Reagent system (Promega). Experiments were repeated in the presence of $5 \mu \mathrm{M}$ of estrogenic $\mathrm{B}[a] \mathrm{P}$ metabolites or $1 \mathrm{nM}$ EE and dose-dependent inhibition with fulvestrant was measured. The magnitude of the Renilla luciferase signal showed that the variability introduced by transient transfection was less than 3\%. All experiments were replicated in three independent experiments.

\section{Cell proliferation and imaging}

Cell proliferation assays were conducted through highcontrast brightfield counting via the Cytation 5 Cell Imaging Multi-Mode Reader (BioTek Instruments) every $24 \mathrm{~h}$ post-treatment. Images were captured at $4 \times$ in the brightfield channel. Two high-contrast brightfield images were captured at each time point: an in-focus image used for reference, and a defocused image for cell counting. Image preprocessing was used to obtain the best possible enhancement of contrast, reducing each cell to a single bright spot. Gen5 software applied masks to identify each 
cell for counting. All experiments were replicated in three independent experiments.

\section{Western blot analysis}

Ishikawa cells $\left(\sim 3.2 \times 10^{6}\right)$ were treated with $10 \mathrm{nM}$ or $100 \mathrm{nM} \mathrm{B}[a] \mathrm{P}-7,8$-dione in a time course $(5,10,30$, 60 and $120 \mathrm{~min}$ ). Cells were washed in ice-cold PBS, and whole-cell extracts were prepared in lysis buffer containing radioimmunoprecipitation assay buffer (RIPA buffer) (Thermofisher) and 1 tablet of protease inhibitor cocktail (Roche). Cells were collected, and debris was pelleted by centrifugation at $15,000 \boldsymbol{g}$ for 10 $\min$ at $4^{\circ} \mathrm{C}$. The supernatants were collected and stored at $-20^{\circ} \mathrm{C}$. Total protein $(40 \mu \mathrm{g})$ was loaded onto $10 \%(\mathrm{v} / \mathrm{v})$ SDS-PAGE gels, separated, and transferred to nitrocellulose. Membranes were incubated with monoclonal mouse phospho-p44/42 MAPK (Erk1/2) (Thr202/Tyr204) (\#9106) or polyclonal rabbit p44/42 MAPK (\#9102) (Cell Signaling Technology). Bound antibodies were detected using horseradish peroxidase-conjugated secondary antibodies and chemiluminescent immunodetection with an ECL Detection Kit (GE Healthcare), and were visualized using the Bio-Rad ChemiDoc imaging system. In each case, three independent experiments were performed, followed by densitometric analysis and one-way ANOVA statistical analysis.

\section{Results}

\section{Characterization of Ishikawa cells}

Ishikawa cells were shown to express ER $\alpha, \operatorname{ER} \beta$ and AhR by immunoblot analysis. We demonstrated the function of the AhR by measuring the induction of P450 activity using the AhR ligand TCDD to induce ethoxyresorufin $\mathrm{O}$-deethylase activity and the function of the ER by measuring the induction of the estrogenresponsive alkaline phosphatase activity using EE as a ER ligand (Supplementary Figs 1, 2 and 3, see section on supplementary materials given at the end of this article).

\section{Stable-isotope dilution LC-APCI-MS/MS detection of $\mathrm{B}[a] \mathrm{P}$ metabolism in Ishikawa cells}

To study $\mathrm{B}[a] \mathrm{P}$ metabolism in Ishikawa cells, we implemented an APCI interface since it is more sensitive than electrospray ionization (ESI) in detecting $\mathrm{B}[a] \mathrm{P}$ metabolites (Koeber et al. 1997). B[a]P and its metabolite standards $\quad(\mathrm{B}[a] \mathrm{P}-7,8-$ trans-dihydrodiol, $\mathrm{B}[a]$ P-tetraols, 3-OH-B $[a] \mathrm{P}$ and $\mathrm{B}[a] \mathrm{P}-7,8$-dione) were directly infused to optimize ionization conditions for their identification. All the hydroxylated standards under positive APCI conditions were predominated by stable dehydrated precursors (see 'Materials and methods' section). Representative LC-SRM/MS chromatograms that demonstrate excellent separation and detection for all the analytes are shown in Fig. 1. Representative ion chromatograms of $\mathrm{B}[a] \mathrm{P}$ metabolites and corresponding internal standards are shown in Supplementary Fig. 4. The peak area ratios of analyte and corresponding isotope-labeled internal standard were plotted against the added amount of analyte to generate calibration curves. For all standards analyzed, excellent linearity was found with $R^{2} \geq 0.99$ (Supplementary Fig. 5).

With the method established, Ishikawa cells were then incubated with $5 \mu \mathrm{M} \mathrm{B}[a] \mathrm{P}$ with or without prior P450 induction by TCDD, and metabolites were measured by SID-LC-APCI-MS/MS protocol over a $24 \mathrm{~h}$ time course. Representative ion chromatograms of $\mathrm{B}[a] \mathrm{P}$ at 0 and $24 \mathrm{~h}$ are shown in Fig. 2. Over 3-24 h, B[a]P was depleted from the media and was taken up into the cells so that 2 $\mu \mathrm{M}$ of $\mathrm{B}[a] \mathrm{P}$ was in the cellular component after 3-24 $\mathrm{h}$ in both the presence or absence of TCDD induction (Fig. 3A). 3-OH-B $[a]$ P was the first metabolite to appear, and it was formed in greater amounts and at an earlier time point following TCDD induction. The formation of $\mathrm{B}[a] \mathrm{P}-7,8$-dione occurred later than 3-OH-B $[a] \mathrm{P}$ (Fig. 3B). Following TCDD induction $\mathrm{B}[a] \mathrm{P}-7,8$-dione was formed

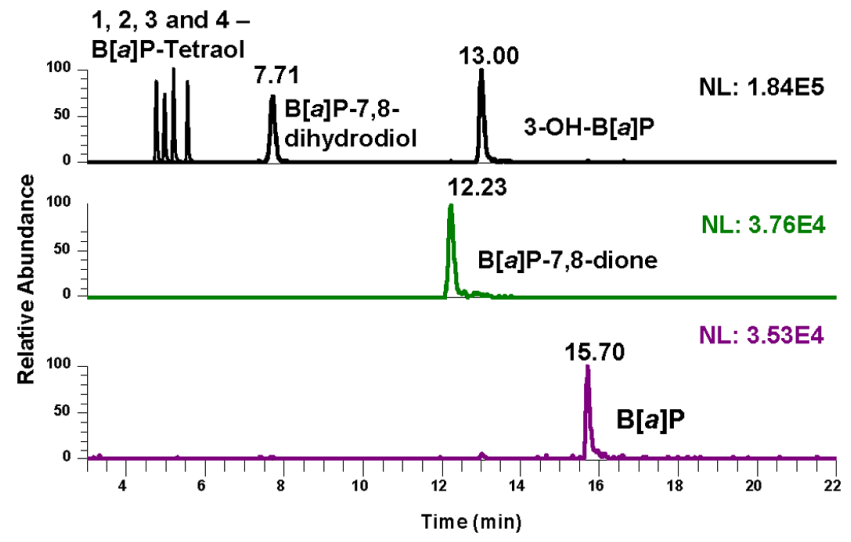

Figure 1

HPLC separation and resulting ion chromatograms of $\mathrm{B}[a] \mathrm{P}$ metabolites. Successful separation of $\mathrm{B}[a] \mathrm{P}$ tetraols (1-4), $\mathrm{B}[a] \mathrm{P}-7,8$-trans-dihydrodiol, 3-OH-B $[a] \mathrm{P}, \mathrm{B}[a] \mathrm{P}-7,8$-dione and $\mathrm{B}[a] \mathrm{P}$ after injection of a mixture of $200 \mathrm{pM}$ of each onto the column connected to an APCI-MS ion source. $A$ representative ion chromatogram is shown. Retention times are indicated above the apex of each peak. A full colour version of this figure is available at https://doi.org/10.1530/JOE-19-0579. 


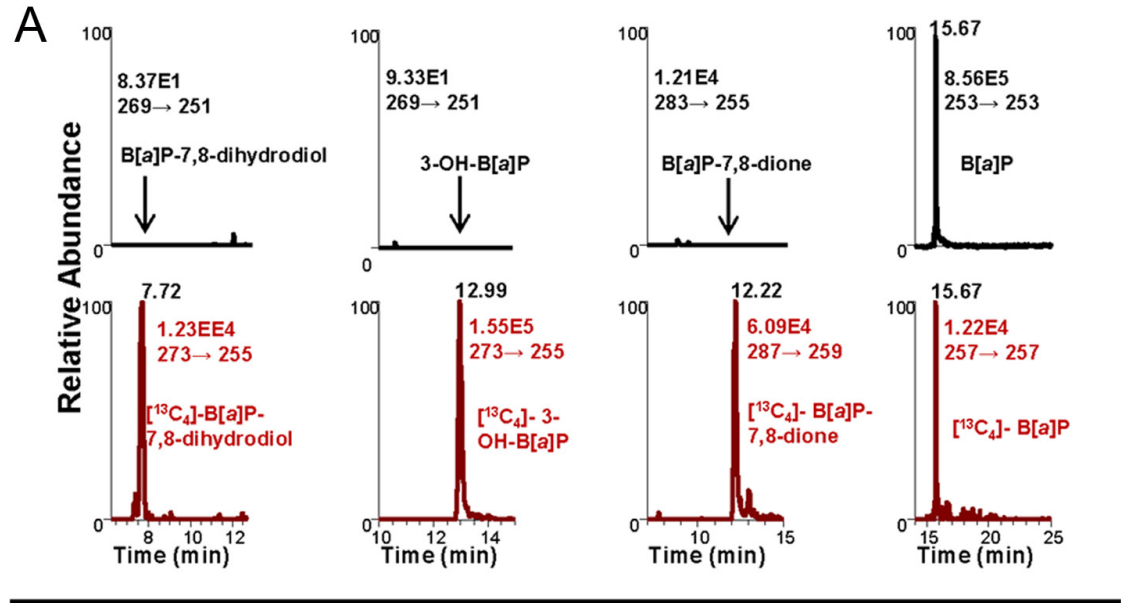

\title{
$\mathrm{B}$
}
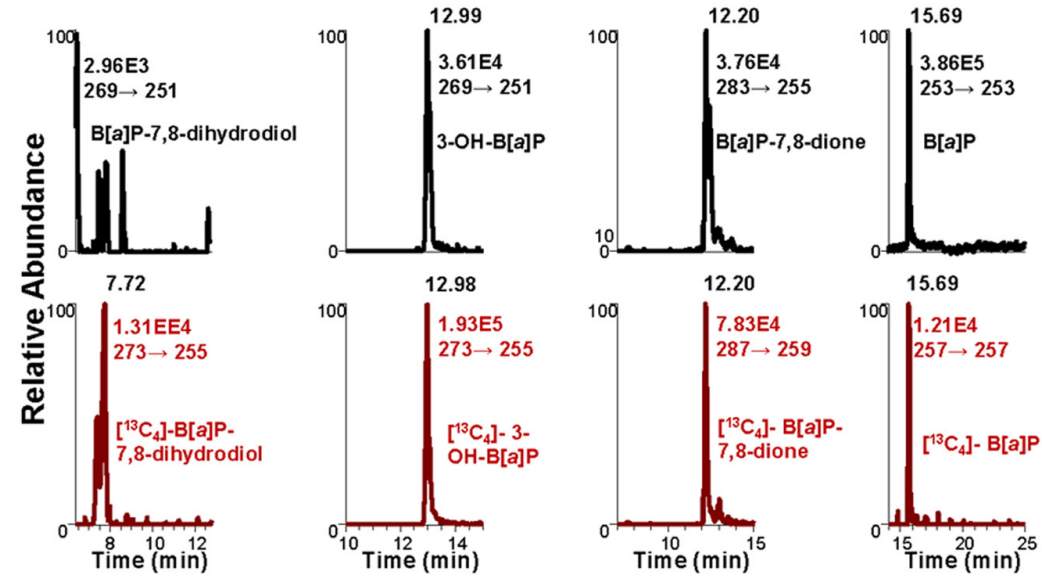

\begin{abstract}
Figure 2
Ion chromatograms of $\mathrm{B}[a] \mathrm{P}$ metabolites formed in Ishikawa cells over $24 \mathrm{~h}$. (A) At $0 \mathrm{~h}$ there are no $\mathrm{B}[a] \mathrm{P}$ metabolites present in the media, but unmetabolized B $[a] \mathrm{P}$ was present. (B) At $24 \mathrm{~h}$ 3-OH-B $[a] \mathrm{P}$ and $\mathrm{B}[a] \mathrm{P}-7,8$-dione were present in the media while $\mathrm{B}[a] \mathrm{P}-7,8$-trans-dihydrodiol is absent and $\mathrm{B}[a] \mathrm{P}$ is depleted. The ion chromatograms of the corresponding $\left[{ }^{13} \mathrm{C}_{4}\right]$ internal standards are shown. A full colour version of this figure is available at https://doi. org/10.1530/JOE-19-0579.
\end{abstract}

in greater amounts and occurred at an earlier time point. With and without induction by TCDD, B $[a] \mathrm{P}-7,8-$ dione formation lagged behind 3-OH-B $[a] \mathrm{P}$ formation (Fig. 3C). Collectively, unmetabolized $\mathrm{B}[a] \mathrm{P}, 3-\mathrm{OH}-\mathrm{B}[a] \mathrm{P}$ and $\mathrm{B}[a] \mathrm{P}-7,8$-dione accounted for $70 \%$ of the $\mathrm{B}[a] \mathrm{P}$ added. There was no evidence for the appearance of $\mathrm{B}[a] \mathrm{P}-7,8$-trans-dihydrodiol or $\mathrm{B}[a] \mathrm{P}$-tetraols in the organic soluble metabolites with or without TCDD induction of P4501A1/1B1 (data not shown).

\section{Measurement of the estrogenic activity of $\mathrm{B}[a] \mathrm{P}$ and its metabolites in Ishikawa cells}

We took advantage of the endogenous reporter gene, alkaline phosphatase (AlkP), which is inducible by estrogens and other estrogenic compounds. The activity of the AlkP enzyme can be easily quantified in situ using a chromogenic substrate (Littlefield et al. 1990). Previous studies show that estradiol induces AlkP at concentrations as low as $10^{-12} \mathrm{M}$ and antiestrogens completely block this effect. We confirmed this finding using EE to activate

AlkP and fulvestrant to inhibit it (Supplementary Fig. 3). The induction AlkP in Ishikawa is specific for estrogens and no other steroids tested, including androgens, progestins, mineralocorticoids or glucocorticoids induce AlkP; therefore these responses have been regarded to be solely mediated by ER (Littlefield et al. 1990).

Cells were treated with 3-OH-B $[a] \mathrm{P}, \mathrm{B}[a] \mathrm{P}-7,8$-transdihydrodiol, $\quad \mathrm{B}[a] \mathrm{P}-9,10-$ trans-dihydrodiol, $\quad \mathrm{B}[a] \mathrm{P}-7,8-$ dione, $\mathrm{B}[a] \mathrm{P}-4,5$-dione, $\mathrm{B}[a] \mathrm{P}-6,12$-dione, $\mathrm{B}[a] \mathrm{P}-1,6$-dione, $\mathrm{B}[a] \mathrm{P}-3,6$-dione and $\mathrm{B}[a] \mathrm{P}-\mathrm{r}-7, \mathrm{t}-8, \mathrm{t}-9, \mathrm{c}-10$-tetrahydrotetrol $(\mathrm{B}[a] \mathrm{P}$-tetraol-1) in a concentration dependent manner between $10^{-1}$ and $10^{4} \mathrm{nM}$. Higher concentrations of these compounds were either insoluble or were cytotoxic in cell culture. $\mathrm{B}[a] \mathrm{P}, 3-\mathrm{OH}-\mathrm{B}[a] \mathrm{P}, \mathrm{B}[a] \mathrm{P}-9,10-$ trans-dihyrodiol and $\mathrm{B}[\mathrm{a}] \mathrm{P}-7,8$-dione stimulated AlkP activity, while the rest of the metabolites tested yielded a less than 1-fold increase in AlkP activity (Supplementary Fig. 6). The induction of AlkP with $5 \mu \mathrm{M} \mathrm{B}[a] \mathrm{P}, 3-\mathrm{OH}-\mathrm{B}[a] \mathrm{P}, \mathrm{B}[a] \mathrm{P}-9,10$-trans-dihydrodiol and $\mathrm{B}[a] \mathrm{P}-7,8$-dione was also inhibited by fulvestrant in a dose-dependent manner indicating that this activity was driven by ER (see representative Supplementary Fig. 7). 
- Media TCDD Induced

$\rightarrow$ Cell TCDD Induced

- Media Uninduced

$\rightarrow$ Cell Uninduced

空 2
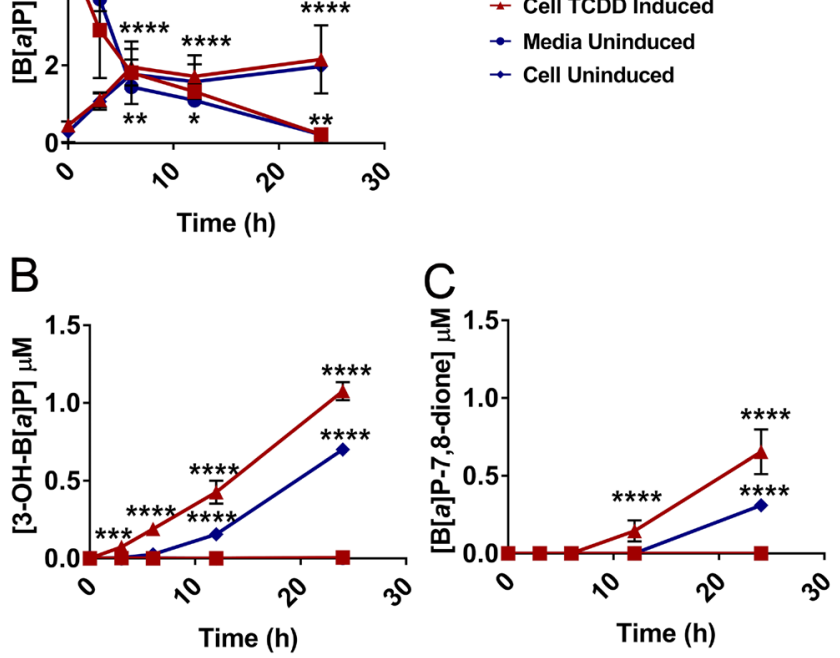

Figure 3

Quantification of $B[a] P$ and metabolites formed in Ishikawa cells over $24 \mathrm{~h}$. (A) B[a]P metabolism was measured over $24 \mathrm{~h}$ and the distribution of metabolites were measured in the media and cellular components. (B) Quantification of 3-OH-B[a]P in TCDD-induced and uninduced treated cells. (C) Quantification of B[a]P-7,8-dione in TCDD-induced and uninduced treated cells, see Materials and Methods for details. Mean values $\pm \mathrm{SD}$ of $\mathrm{n}=3$ independent experiments are given. ${ }^{*} P \leq 0.05$; $* \star P \leq 0.01 ; * * * P \leq 0.001 ; * * * * P \leq 0.0001$. One-way ANOVA was performed using GraphPad Prism. A full colour version of this figure is available at https://doi.org/10.1530/JOE-19-0579.

\section{Induction of ERE luciferase activity by B[a]P and metabolites in Ishikawa cells}

Our findings from the AlkP assays showed that $\mathrm{B}[a] \mathrm{P}$, 3-OH-B $[a] \mathrm{P}$ and $\mathrm{B}[a] \mathrm{P}-7,8$-dione metabolites were estrogenic using an endogenous reporter gene. We were concerned that the AlkP assay may not have been sensitive enough to detect the true potency of the estrogenic effects of $\mathrm{B}[a] \mathrm{P}$ metabolites. To address this question, we used a more sensitive ERE luciferase activity assay and measured estrogenic activity using this exogenous reporter gene. Cells were transiently transfected with an ERE-luciferase reporter plasmid and luciferase activity was determined after $24 \mathrm{~h}$ treatment with test compounds as a measure of ER-mediated transcriptional activation. We found that the $\mathrm{EC}_{50}$ values obtained were similar to those observed in the AlkP assay but the fold induction with all ER ligands was greater (Fig. $4 \mathrm{~A})$. We also found that the luciferase activity induced by the $\mathrm{B}[a] \mathrm{P}$ metabolites was inhibited by fulvestrant in a dose-dependent manner (Fig. 4B).
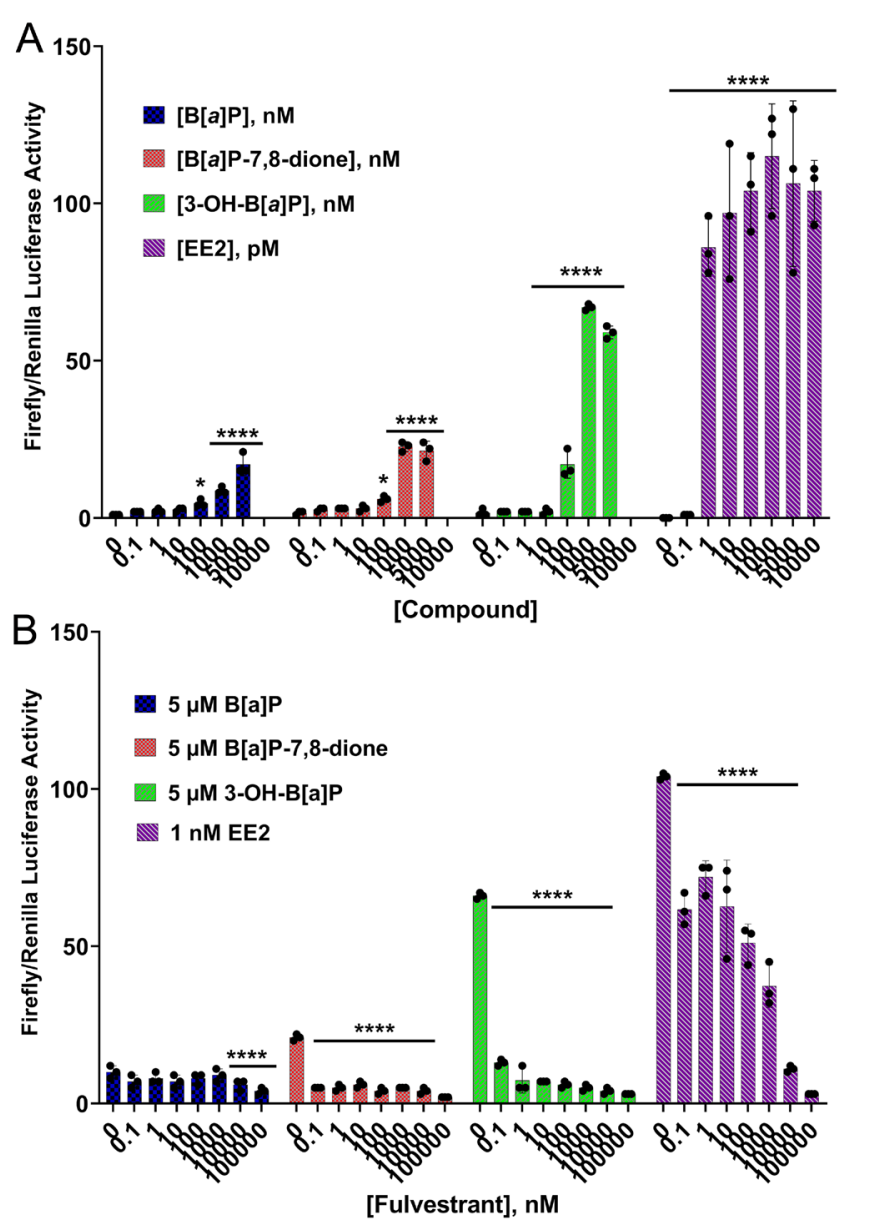

Figure 4

Induction of ERE luciferase activity by $\mathrm{EE}, \mathrm{B}[\alpha] \mathrm{P}$ and its metabolites and its inhibition by fulvestrant. (A) B $[a] \mathrm{P}, \mathrm{B}[a] \mathrm{P}-7,8$-dione, and 3-OH-B $[a] \mathrm{P}$ induced ERE luciferase activity in a concentration-dependent manner with $E_{50}$ values in the low micromolar range, by comparison EE, induced ERE luciferase in the low nanomolar range. (B) Induction of ERE luciferase activity by $5 \mu \mathrm{M} \mathrm{B}[a] \mathrm{P}, 5 \mu \mathrm{M}$ B[$[a] \mathrm{P}-7,8$-dione, $5 \mu \mathrm{M}$ 3-OH-B $[a] \mathrm{P}$ and $1 \mathrm{nM}$ EE is inhibited by fulvestrant, an ER antagonist in a dose-dependent manner. EE2 = ethinyl estradiol. ERE luciferase activity was measured $24 \mathrm{~h}$ post-treatment, see 'Materials and methods' section. Mean values \pm S.D. of $n=3$ independent experiments are given. ${ }^{*} P \leq 0.05 ; * \star * * P \leq 0.0001$. One-way ANOVA followed by Dunnett's multiple comparisons test was performed using GraphPad Prism. A full colour version of this figure is available at https://doi.org/10.1530/JOE-19-0579.

Induction of MCF-7 breast cancer cell proliferation by 17 $\alpha$-ethinyl estradiol (EE) and B[a]P-7,8-dione and inhibition with fulvestrant

MCF-7 cells have an established estrogen-dependent proliferation phenotype that we sought to utilize as a positive control for imminent experiments in endometrial cells. We treated MCF-7 cells with EE and B[a]P-7,8-dione in a concentration-dependent manner, $10^{-1}$ and $10^{4} \mathrm{pM}$ for EE and between $10^{-1}$ and $10^{4} \mathrm{nM}$ for $\mathrm{B}[a] \mathrm{P}-7,8$-dione. 


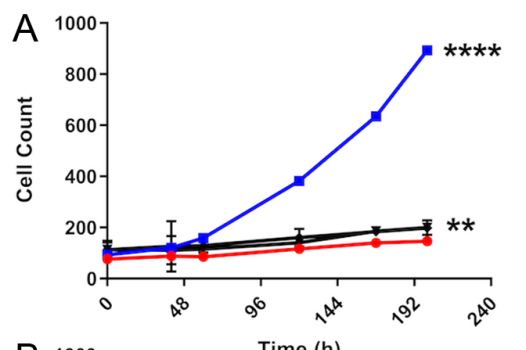

- $0.1 \%$ DMSO

$-100 \mathrm{pM} \mathrm{EE}$

100 pM EE +

* $100 \mathrm{nM}$ Fulvestrant

$100 \mathrm{pM} \mathrm{EE}+$

$\rightarrow 1000$ nM Fulvestrant

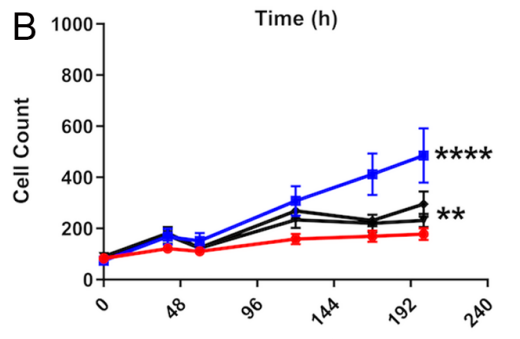

- $0.1 \%$ DMSO

- $1 \mu \mathrm{M} \mathrm{B}[\mathrm{a}] \mathrm{P}-7,8$-dione

$+1 \mu \mathrm{M}$ B[a]P-7,8-dione + $100 \mathrm{nM}$ Fulvestrant

$1 \mu \mathrm{M} \mathrm{B}[\mathrm{a}] \mathrm{P}-7,8$-dione + 1000 nM Fulvestrant

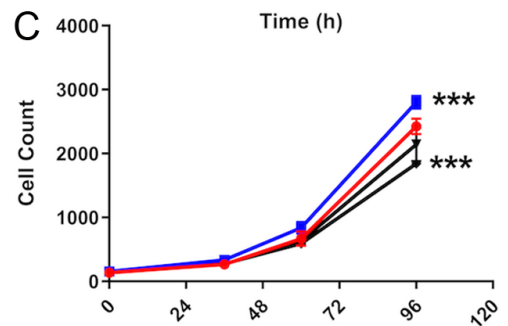

$\rightarrow 0.1 \% \mathrm{DMSO}$

- $10 \mathrm{pM} \mathrm{EE}$

$+\quad 10 \mathrm{pM} \mathrm{EE}+$

* $100 \mathrm{nM}$ Fulvestrant

$+10 \mathrm{pM} \mathrm{EE}+$

1000 nM Fulvestrant

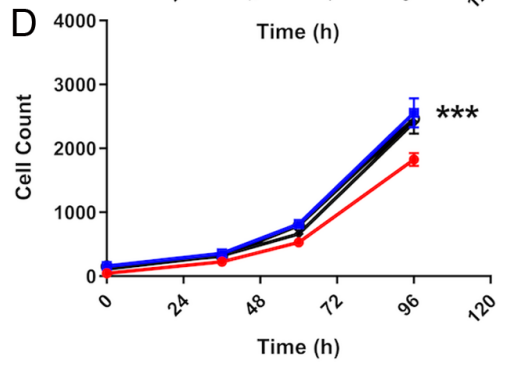

- $0.1 \%$ DMSO

- 10 nM B[a]P-7,8-dione

+10 nM B[a]P-7,8-dione +

- $1000 \mathrm{nM}$ Fulvestrant

$10 \mathrm{nM}$ B[a]P-7,8-dione + $10000 \mathrm{nM}$ Fulvestrant

\section{Figure 5}

Inhibition of EE- and B[a]P-7,8-dione-induced MCF-7 cell and Ishikawa endometrial cell proliferation with fulvestrant. (A) A dose-dependent fulvestrant (ER antagonist) inhibition of 100 pM EE-induced MCF-7 cell proliferation over $192 \mathrm{~h}$. (B) Fulvestrant inhibition of $1 \mu \mathrm{M} \mathrm{B}[a] \mathrm{P}-7-8$ dione-induced MCF-7 proliferation over 192 h. (C) A dose-dependent fulvestrant inhibition of 100 pM EE-induced Ishikawa cell proliferation over $96 \mathrm{~h}$. (D) Lack of complete fulvestrant inhibition of $10 \mathrm{nM} \mathrm{B[a]P-}$ 7-8-dione-induced Ishikawa proliferation over $96 \mathrm{~h}$. Mean values \pm S.D. of $n=3$ independent experiments are given. ${ }^{*} P \leq 0.05 ; * \star * P \leq 0.001$; $\star \star * \star P \leq 0.0001$. One-way ANOVA followed by Dunnett's multiple comparisons test was performed using GraphPad Prism. A full colour version of this figure is available at https://doi.org/10.1530/JOE-19-0579.

Cell proliferation was induced by both $\mathrm{EE}$ and B[a]P-7,8-dione (Supplementary Fig. 8) in a dosedependent manner. The induction of cell proliferation by $100 \mathrm{pM}$ EE (Fig. 5A) and $1 \mu \mathrm{M}$ B[a]P-7,8-dione (Fig. 5B) in MCF-7 cells was inhibited by fulvestrant in a dose-dependent manner, suggesting that both EE- and $\mathrm{B}[\mathrm{a}] \mathrm{P}-7,8$-dione-induced cell proliferation was driven by ERs in the MCF-7 cell line. The concentration at which we saw an effect of $\mathrm{B}[a] \mathrm{P}-7,8$-dione in MCF cells was consistent with its $\mathrm{EC}_{50}$ value for $\mathrm{ER}$ activation in Ishikawa cells. These results were replicated in three independent experiments.

\section{Induction of Ishikawa endometrial cancer cell proliferation by EE and estrogenic PAHs and inhibition with fulvestrant}

Ishikawa endometrial cells were treated with EE $\left(10^{-1}\right.$ to $10^{4} \mathrm{pM}$ ) and estrogenic PAHs - B $[a] \mathrm{P}, \mathrm{B}[a] \mathrm{P}-7,8$-dione and $3-\mathrm{OH}-\mathrm{B}[a] \mathrm{P}$ - in a concentration-dependent manner $\left(10^{-1}\right.$ to $\left.10^{4} \mathrm{nM}\right)$. In total, $1 \mathrm{pM} \mathrm{EE}$ and $10 \mathrm{nM} \mathrm{B}[a] \mathrm{P}-7,8$-dione (Fig. 6) induced a significant increase $(p \leq 0.05)$ in the proliferation of Ishikawa cells while $\mathrm{B}[a] \mathrm{P}$ and $3-\mathrm{OH}-\mathrm{B}[a] \mathrm{P}$ did not exhibit significant cell proliferation and were, in fact, cytotoxic at high concentrations (Supplementary Fig. 9). Notably, contrary to the trend observed in MCF-7 cells, $\mathrm{B}[a] \mathrm{P}-7,8$-dione-induced endometrial cell proliferation in the low $\mathrm{nM}$ range at concentrations insufficient to activate the ER in the alkaline phosphatase and ERE-luciferase reporter gene assays. Fulvestrant inhibited EE stimulated Ishikawa cell growth but did not inhibit $\mathrm{B}[a] \mathrm{P}-7,8$-dioneinduced proliferation in Ishikawa cells (Fig. 5D). These data revealed that $\mathrm{B}[a] \mathrm{P}-7,8$-dione-induced endometrial cell proliferation in an ER-independent manner. In additional experiments, we also found that $\mathrm{B}[a] \mathrm{P}-7,8$ dione and EE induce the expression of the cell cycle gene, CCND1 (Supplementary Fig. 10), and this induction was not inhibited by fulvestrant (Supplementary Fig. 11). We also found $\mathrm{EE}$ and $\mathrm{B}[\mathrm{a}] \mathrm{P}-7,8$-dione to have no effect on apoptosis in the $0.1 \mathrm{nM}$ to $1.0 \mu \mathrm{M}$ concentration range (Supplementary Fig. 12). These supplemental experiments further reveal $\mathrm{B}[a] \mathrm{P}-7,8$-dione-induced endometrial cell proliferation to be a primary outcome of $\mathrm{B}[a] \mathrm{P}-7,8$-dione signaling in endometrial cells, as opposed to apoptosis.

\section{Inhibition of $\mathrm{B}[\mathrm{a}] \mathrm{P}-7,8-$ dione-induced endometrial cell proliferation by EGFR-selective tyrosine kinase inhibitor-gefitinib}

In an effort to decipher a mechanism for $\mathrm{B}[a] \mathrm{P}-7,8$ dione-induced endometrial cell proliferation that was independent of ER, we explored the role of EGFR since previous studies suggested that $\mathrm{B}[a] \mathrm{P}$ quinones can induce MCF-7 cell proliferation by activation of the EGFR (Burdick et al. 2003). Cell proliferation was induced in Ishikawa cells using $10 \mathrm{nM} \mathrm{B}[a] \mathrm{P}-7,8$-dione in the presence and absence of the EGFR-selective tyrosine kinase inhibitor (gefitinib). We observed a dose-dependent inhibition of $\mathrm{B}[a] \mathrm{P}-7,8$ dione-induced proliferation by gefitinib in Ishikawa 


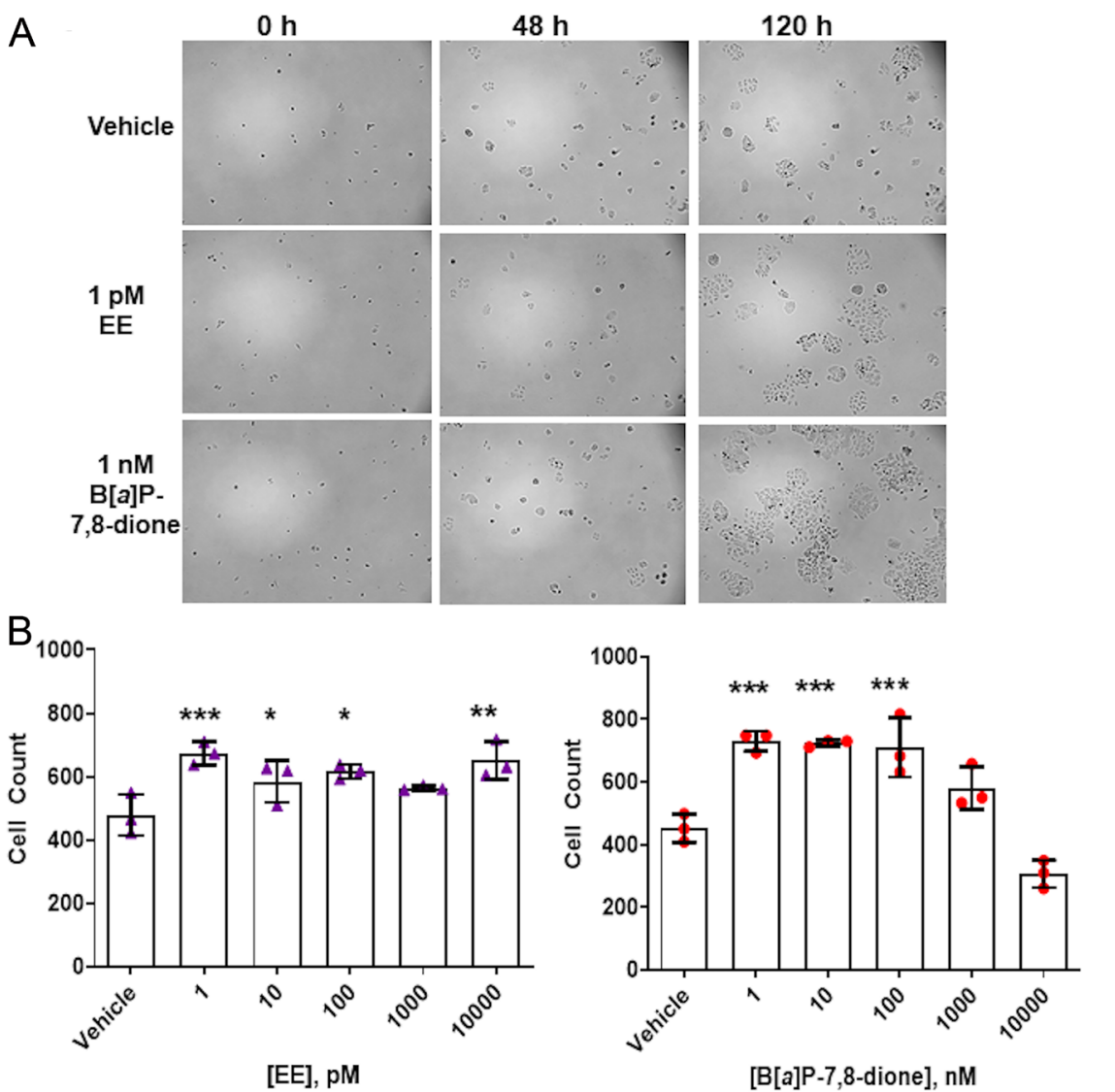

\begin{abstract}
Figure 6
Induction of Ishikawa cell proliferation with $\mathrm{EE}$ and $\mathrm{B}[\mathrm{a}] \mathrm{P}-7,8$-dione. (A) $\mathrm{EE}(1 \mathrm{pM})$ and $\mathrm{B}[a] \mathrm{P}-7,8$-dione (1 $\mathrm{nM}$ ) induce Ishikawa cell proliferation and (B) EE and B[a]P-7-8-dione induce Ishikawa cell proliferation in a dosedependent manner. Mean values \pm S.D. of $n=3$ independent experiments are given. ${ }^{*} P \leq 0.05$; $\star \star * P \leq 0.001 ; * \star \star * P \leq 0.0001)$. One-way ANOVA was performed using GraphPad Prism. A full colour version of this figure is available at https:// doi.org/10.1530/JOE-19-0579.
\end{abstract}

cells (Fig. 7A). These results suggest that EGFR activation is implicated in $\mathrm{B}[a] \mathrm{P}-7,8$-dione-induced endometrial cell proliferation. These results were replicated in three independent experiments.

\section{Inhibition of $\mathrm{B}[a] \mathrm{P}-7,8-$ dione-induced endometrial cell proliferation by MAPK inhibitor - PD98059}

We wanted to determine whether the MAPK pathway was involved in $\mathrm{B}[a] \mathrm{P}-7,8$-dione-induced cell proliferation of Ishikawa cells. Cell proliferation was induced in Ishikawa cells using $10 \mathrm{nM} \mathrm{B}[a] \mathrm{P}-7,8$-dione in the presence and absence of the MAPK inhibitor, PD98059. We observed a dose-dependent inhibition of $\mathrm{B}[a] \mathrm{P}-7,8$-dione-induced proliferation by PD98059 in Ishikawa cells (Fig. 7B). These results suggest that $\mathrm{B}[a] \mathrm{P}-7,8$-dione-induced endometrial cell proliferation and implicated the MAPK pathway. These results were replicated in three independent experiments.

\section{Phosphorylation of p44/42 MAPK by nM concentrations of $\mathrm{B}[a] \mathrm{P}-7,8-$ dione in Ishikawa cells}

We confirmed the activation of MAPK pathway by immunoblotting for phospho p44/42 MAPK (ERK1/ERK2) after treating Ishikawa cells with $\mathrm{nM}$ concentrations of $\mathrm{B}[\mathrm{a}] \mathrm{P}-7,8$-dione. In a time course spanning $5 \mathrm{~min}$ to $2 \mathrm{~h}$ we observed an increase in p44/42 MAPK phosphorylation that peaked at $30 \mathrm{~min}$ (Fig. 8) for both $10 \mathrm{nM}$ and $100 \mathrm{nM}$ $\mathrm{B}[a] \mathrm{P}-7,8$-dione treated cells. These results confirm our hypothesis that the MAPK pathway is indeed implicated in $\mathrm{B}[a] \mathrm{P}-7,8$-dione-induced endometrial cell proliferation. These results were replicated in three independent experiments.

\section{Discussion}

Endometrial cancer is the most common malignancy within the female reproductive system (Siegel et al. 2019). Exposure of the endometrium to unopposed estrogens from endogenous and exogenous sources is of concern as it has been shown to be the main driver of endometrial cancer. Polycyclic aromatic hydrocarbons (PAHs) have been extensively studied for their mutagenic and carcinogenic activities (Kummer et al. 2008). However, they also engender non-genotoxic effects associated with tumor promotion or endocrine disruption (Sjogren et al. 1996, Pliskova et al. 2005, Andrysik et al. 2007), 


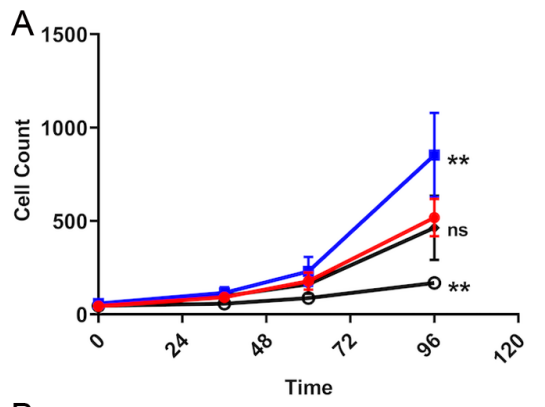

- $0.1 \%$ DMSO

- $10 \mathrm{nM} \mathrm{B}[\mathrm{a}] \mathrm{P}-7,8$-dione

$+10 \mathrm{nM}$ B[a]P-7,8-dione +

$\leftarrow 1000 \mathrm{nM}$ Gefitinib

$10 \mathrm{nM}$ B[a]P-7,8-dione + $10000 \mathrm{nM}$ Gefitinib

B

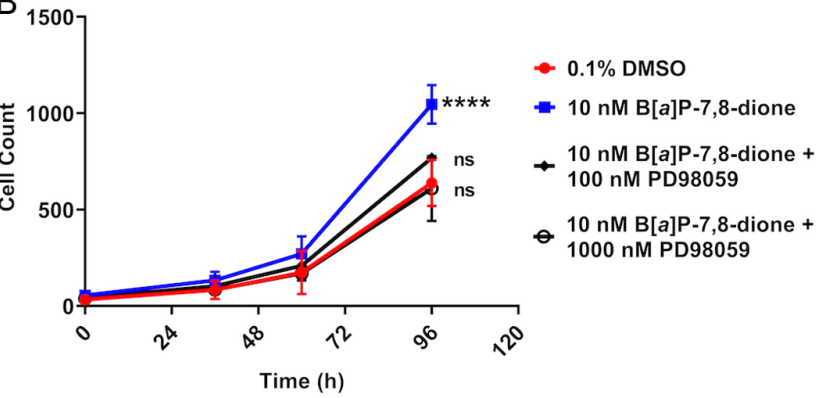

Figure 7

Inhibition of B[a]P-7,8-dione-induced endometrial cell proliferation with EGFR and MAPK inhibitors, gefitinib and PD98059, respectively. (A) The EGFR inhibitor (gefitinib) dose-dependent inhibition of Ishikawa cell proliferation induced by $10 \mathrm{nM} \mathrm{B}[a] \mathrm{P}-7,8$-dione over $96 \mathrm{~h}$. (B) The MAPK inhibitor (PD98059) dose-dependent inhibition of Ishikawa cell proliferation induced by $10 \mathrm{nM} \mathrm{B}[a] \mathrm{P}-7,8$-dione over $96 \mathrm{~h}$. Mean values \pm S.D. of $n=3$ independent experiments are given. ${ }^{*} P \leq 0.01 ; * * * * P \leq 0.0001 ; \mathrm{ns}$, not significant. One-way ANOVA was performed using GraphPad Prism. A full colour version of this figure is available at https://doi.org/10.1530/ JOE-19-0579.

and others have shown PAHs and/or their metabolites to have xenoestrogenic activity in rodent and human breast cell line models (Arcaro et al. 1999, Charles et al. 2000, Fertuck et al. 2001, Gozgit et al. 2004, Abdelrahim et al. 2006). Activation of ER signaling in endocrine target tissues, such as the endometrium, may further contribute to the known carcinogenicity of PAHs (Santodonato 1997). While some work has been done to study reproductive toxicity associated with endometrial cell-mediated metabolism of PAHs (Iannaccone et al. 1984), insufficient information exists concerning the metabolic activation and estrogenic activity of $\mathrm{PAH}$ in human endometrial cells. The signaling mechanisms and biological outcomes of estrogenic and non-estrogenic signaling induced by PAH in endometrial cells also remain to be clarified.

We demonstrate that the Ishikawa endometrial cell line is appropriate for investigating the metabolic fate and estrogenic activity of $\mathrm{B}[a] \mathrm{P}$ and its metabolites. This cell line contains the AhR and ERs (Supplementary Fig. 1) and is responsive to the induction of cytochrome P450s (P450s) and estrogenic activity by TCDD and EE, respectively (Supplementary Figs 2 and 3).
Utilizing stable-isotope dilution high performance liquid chromatography and APCI tandem mass spectrometry in the selected reaction monitoring mode (LC/APCI/MS/MS), we characterized and quantified $\mathrm{B}[a] \mathrm{P}$ and its metabolites in the presence and absence of P450 induction by TCDD an AhR agonist. We found that $\mathrm{B}[\mathrm{a}] \mathrm{P}$ can be metabolized in Ishikawa cells to significant levels of $3-\mathrm{OH}-\mathrm{B}[a] \mathrm{P}$ and $\mathrm{B}[\mathrm{a}] \mathrm{P}-7,8$-dione, with the induction of $\mathrm{P} 450$ s resulting in the formation of higher levels of both products. We tested the estrogenic activity of these metabolites using the inducible endogenous alkaline phosphatase reporter activity and the exogenous estrogen response element (ERE) driven luciferase reporter activity in Ishikawa cells. We demonstrated that $\mathrm{B}[a] \mathrm{P}$ metabolites formed in Ishikawa cells can activate the ER in both assays and that the reporter gene activity was blocked with fulvestrant. We also found that $\mathrm{B}[a] \mathrm{P}-7,8$-dione promoted endometrial cell proliferation at nanomolar concentrations insufficient to activate the ER, and implicated EGFR and MAPK signaling in this response.

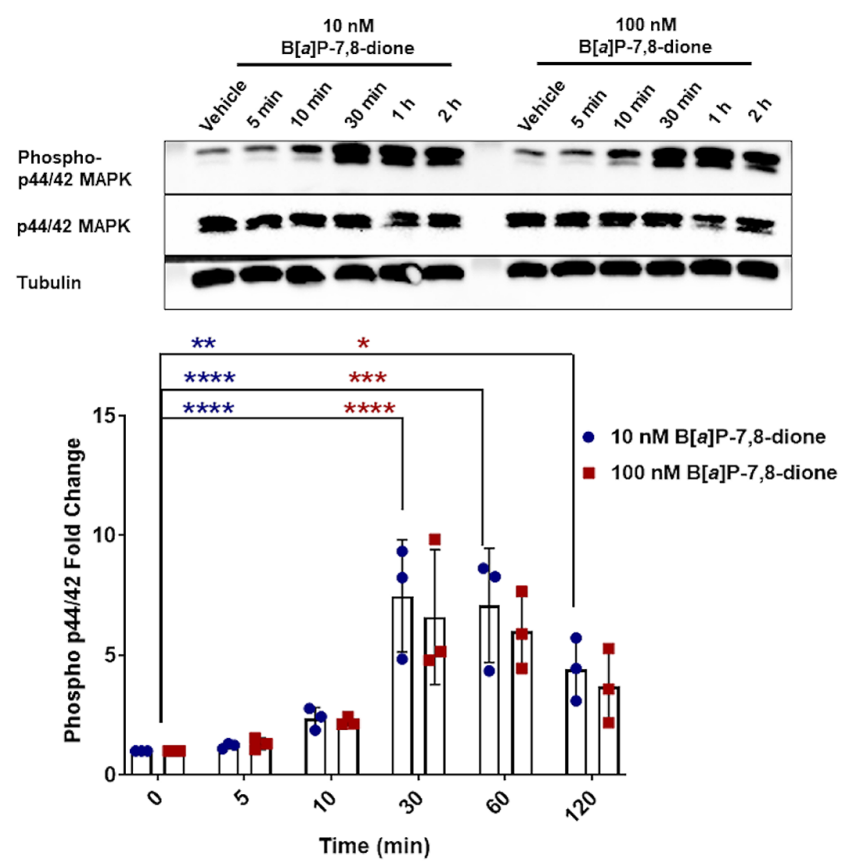

Figure 8

Concentration-dependent activation of MAPK by B $[a]$ P-7,8-dione in Ishikawa cells. Top panel immunoblot showing $10 \mathrm{nM} \mathrm{B}[a] \mathrm{P}-7,8$-dione and $100 \mathrm{nM} \mathrm{B}[a] \mathrm{P}-7,8-$ dione induction of p44/42 MAPK phosphorylation over at 5, 10, 30 min and $2 \mathrm{~h}$. Tubulin is used as the loading control. Bottom panel densitometric quantitation of the immunoblot showing fold change of phosphor p44/42 over vehicle. Mean values \pm s.D. of $n=3$ independent experiments are given. $* P \leq 0.05 ; * * * P \leq 0.001 ; * * * * P \leq 0.0001$. One-way ANOVA was performed using GraphPad Prism. A full colour version of this figure is available at https://doi.org/10.1530/JOE-19-0579. (c) 2020 Society for Endocrinology Published by Bioscientifica Ltd. Printed in Great Britain 
Our study identified the main pathways of PAH metabolism in endometrial cells, and we identified the most important estrogenic PAH metabolites following $\mathrm{PAH}$ exposure that may act as endocrine-disrupting chemicals. 3-OH-B $[a] \mathrm{P}$ and $\mathrm{B}[a] \mathrm{P}-7,8$-dione were the main metabolites formed revealing evidence for P450-mediated mono-oxygenation and the $o$-quinone pathway. The latter requires the sequential action of P450, epoxide hydratase and aldo-keto reductases (Penning 2014). PAHs have previously been shown to engender estrogenic activity in rodent models and breast cancer cell lines but not in human endometrial cells; thus this work is significant because it illustrates the estrogenic character of PAHs and their metabolites in these cells. It is noteworthy that $\mathrm{B}[a] \mathrm{P}-7,8$-dione can redox cycle to the corresponding catechol, and B[a]P-7,8-catechol has structural similarity to catechol estrogens, which have genotoxic properties (Rempel et al. 2009, Wang et al. 2009, 2010, Fussell et al. 2011). Thus B[a]P-7,8-dione formed may play a significant role in endometrial cell genotoxicity in addition to its estrogenic action.

We assessed cell proliferation mediated by the estrogenic PAH metabolites because it is the primary phenotype attributed to estrogen signaling in female endocrine cancers. As a positive control, we observed a concentration-dependent increase in cell proliferation in MCF-7 breast cancer cells treated with EE, confirming previous results (Soto \& Sonnenschein 1985, Furuya et al. 1989, Liao et al. 2014). B[a]P-7,8-dione exhibited a growth phenotype in MCF-7 cells at concentrations that elicit an estrogen response in our reporter gene assays which was inhibited by fulvestrant, suggesting that $\mathrm{B}[a] \mathrm{P}-7,8$-dione-induced cell proliferation was ER-dependent in this cell line. When we applied the same protocol to Ishikawa endometrial cells, we also observed an increase in proliferation after treatment with increasing concentrations of $\mathrm{EE}$, and this response was attenuated by fulvestrant. Of the PAH metabolites tested only B $[a]$ P-7,8-dione-induced Ishikawa cell proliferation but this effect was observed in the low nM range, at concentrations insufficient to activate the ER. Moreover, the growth phenotype in Ishikawa cells mediated by $\mathrm{B}[a] \mathrm{P}-7,8$-dione was not blocked by fulvestrant. We also investigated the effects of $\mathrm{EE}$ and $\mathrm{B}[a] \mathrm{P}-7,8$-dione on the induction of the cell cycle gene CCND1 and found both to induce the expression of this gene in a dose-dependent manner. However, fulvestrant did not inhibit the induction of EE- and $\mathrm{B}[a] \mathrm{P}-7,8$-dione-induced CCND1 expression. Additionally, we found both EE- and $\mathrm{B}[a] \mathrm{P}-7,8$-dione to not induce apoptosis in Ishikawa cells in the $0.1 \mathrm{nM}$ to $1 \mu \mathrm{M}$ range. These results suggest that $\mathrm{B}[a] \mathrm{P}-7,8$-dione-induced endometrial cell proliferation may not be ER-regulated.

Given that $\mathrm{B}[a] \mathrm{P}$ quinones can induce EGFR signaling via ROS in breast epithelial cells (Burdick et al. 2003). We demonstrated that EGFR-selective receptor tyrosine kinase and MAPK inhibitors, gefitinib and PD98059, respectively, inhibit $\mathrm{B}[a] \mathrm{P}-7,8$-dione-induced cell proliferation in Ishikawa cells. Additionally, exposing Ishikawa cells to $\mathrm{nM}$ concentrations of $\mathrm{B}[a] \mathrm{P}-7,8$-dione resulted in the phosphorylation of p44/42 MAPK (ERK 1/2). These data suggest that the MAPK pathway is implicated in $\mathrm{B}[a] \mathrm{P}-7,8$ dione-induced endometrial cell proliferation.

Our work unveils two properties of PAHs and their metabolites in human endometrial cells. PAHs are estrogenic in human endometrial cells in the $\mu \mathrm{M}$ concentration range but not the $\mathrm{nM}$ range. On the other hand, low concentrations (nM range) of $\mathrm{B}[a] \mathrm{P}-7,8$-dione elicit a growth phenotype in endometrial cells that do not seem to be modulated by ERs but implicate the MAPK pathway. Reactive oxygen species (ROS) are not only toxic to cells but can also modulate signaling during tumor progression. For instance, it has previously been demonstrated that the oxidation of protein cysteine (Cys) residues in EGFR and downstream phosphatases by ROS enhances EGFR-mediated signaling to promote tumor progression (Weng et al. 2018). The redox-cycling of $\mathrm{B}[a] \mathrm{P}-7,8$-dione, leading to ROS formation (Burczynski et al. 1999), could explain why it is the only $\mathrm{B}[a] \mathrm{P}$ metabolite formed in Ishikawa cells to induce proliferation implicating the EGFR and MAPK pathways.

In conclusion, we have demonstrated that endometrial carcinoma cells can metabolize $\mathrm{B}[a] \mathrm{P}$ to bioactive metabolites. Of these, both $\mathrm{B}[a] \mathrm{P}-7,8$-dione and $3-\mathrm{OH}-\mathrm{B}[a] \mathrm{P}$ induce ER-dependent gene transcription, but this transcription does not result in cell proliferation. Importantly, low concentrations of $\mathrm{B}[a] \mathrm{P}-7,8$-dione affect endometrial carcinoma proliferation by an ER-independent pathway involving EGFR-MAP-kinase signaling.

\section{Supplementary materials \\ Supplementary data has been deposited in the public data repository figshare:}

Supplementary Figure 1: https://doi.org/10.6084/m9.figshare.11284034.v2 Supplementary Figure 2: https://doi.org/10.6084/m9.figshare.11284052.v2 Supplementary Figure 3: https://doi.org/10.6084/m9.figshare.11284118.v2 Supplementary Figure 4: https://doi.org/10.6084/m9.figshare.12192531.v1 Supplementary Figure 5: https://doi.org/10.6084/m9.figshare.12192543.v1 Supplementary Figure 6: https://doi.org/10.6084/m9.figshare.12192579.v1 Supplementary Figure 7: https://doi.org/10.6084/m9.figshare.12192621.v1 Supplementary Figure 8: https://doi.org/10.6084/m9.figshare.11996658.v1 
Supplementary Figure 9: https://doi.org/10.6084/m9.figshare.11996697.v2 Supplementary Figure 10: https://doi.org/10.6084/m9.figshare.11996727.v1 Supplementary Figure 11: https://doi.org/10.6084/m9.figshare.11996733.v1 Supplementary Figure 12: https://doi.org/10.6084/m9.figshare.11996742.v1

\section{Declaration of interest}

T M P is the founder of Penzymes, LLC, receives a sponsored research agreement from Forendo and is on the expert panel of the Research Institute for Fragrance Materials. Our grant sponsor, National Institute of Environmental Health Sciences, is a non-commercial funding agency and was not involved in the acquisition and interpretation of the data or the decision to publish the work.

\section{Funding}

This work was supported by the National Institute of Environmental Health Sciences, grants P30-ES013508 and R01-ES029294 to T M P and I G L was supported by T32-ES019851.

\section{References}

Abdelrahim M, Ariazi E, Kim K, Khan S, Barhoumi R, Burghardt R, Liu SX, Hill D, Finnell R, Wlodarczyk B, et al. 2006 3-Methylcholanthrene and other aryl hydrocarbon receptor agonists directly activate estrogen receptor alpha. Cancer Research 66 2459-2467. (https://doi org/10.1158/0008-5472.CAN-05-3132)

Andrysik Z, Vondracek J, Machala M, Krcmar P, Svihalkova-Sindlerova L, Kranz A, Weiss C, Faust D, Kozubik A \& Dietrich C 2007 The aryl hydrocarbon receptor-dependent deregulation of cell cycle control induced by polycyclic aromatic hydrocarbons in rat liver epithelial cells. Mutation Research 615 87-97. (https://doi.org/10.1016/j. mrfmmm.2006.10.004)

Arcaro KF, O'Keefe PW, Yang Y, Clayton W \& Gierthy JF 1999 Antiestrogenicity of environmental polycyclic aromatic hydrocarbons in human breast cancer cells. Toxicology 133 115-127. (https://doi. org/10.1016/s0300-483x(99)00018-9)

Armstrong B, Hutchinson E, Unwin J \& Fletcher T 2004 Lung cancer risk after exposure to polycyclic aromatic hydrocarbons: a review and meta-analysis. Environmental Health Perspectives 112 970-978. (https:// doi.org/10.1289/ehp.6895)

Borek-Dohalska L, Klusonova Z, Holecova J, Martinkova M, Barta F, Dracinska H, Cajthaml T \& Stiborova M 2016 Exposure of rats to exogenous endocrine disruptors 17alpha-ethinylestradiol and benzo(a) pyrene and an estrogenic hormone estradiol induces expression of cytochromes P450 involved in their metabolism. Neuro Endocrinology Letters 37 84-94.

Brandenberger AW, Lebovic DI, Tee MK, Ryan IP, Tseng JF, Jaffe RB \& Taylor RN 1999 Oestrogen receptor (ER)- $\alpha$ and ER- $\beta$ isoforms in normal endometrial and endometriosis-derived stromal cells. Molecular Human Reproduction 5 651-655. (https://doi.org/10.1093/molehr/5.7.651)

Burczynski ME, Lin HK, \& Penning TM 1999 Isoform-specific induction of a human aldo-keto reductase by polycyclic aromatic hydrocarbons (AOHs), electrophiles \& oxidative stress: implications for the alternative pathway of PAH activation catalyzed by human dihydrodiol dehydrogenase. Cancer Research 59 607-614.

Burdick AD, Davis JW, Liu KJ, Hudson LG, Shi H, Monske ML \& Burchiel SW 2003 Benzo(a)pyrene quinones increase cell proliferation, generate reactive oxygen species, and transactivate the epidermal growth factor receptor in breast epithelial cells. Cancer Research 63 7825-7833.

Charles GD, Bartels MJ, Zacharewski TR, Gollapudi BB, Freshour NL \& Carney EW 2000 Activity of benzo[a]pyrene and its hydroxylated metabolites in an estrogen receptor-alpha reporter gene assay. Toxicological Sciences 55 320-326. (https://doi.org/10.1093/ toxsci/55.2.320)

Fertuck KC, Kumar S, Sikka HC, Matthews jb \& Zacharewski TR 2001 Interaction of PAH-related compounds with the alpha and beta isoforms of the estrogen receptor. Toxicology Letters 121 167-177. (https://doi.org/10.1016/s0378-4274(01)00344-7)

Furuya Y, Kohno N, Fujiwara Y \& Saitoh Y 1989 Mechanisms of estrogen action on the proliferation of MCF-7 human breast cancer cells in an improved culture medium. Cancer Research 49 6670-6674.

Fussell KC, Udasin RG, Smith PJ, Gallo MA \& Laskin JD 2011 Catechol metabolites of endogenous estrogens induce redox cycling and generate reactive oxygen species in breast epithelial cells. Carcinogenesis 32 1285-1293. (https://doi.org/10.1093/carcin/bgr109)

Gammon MD, Santella RM, Neugut AI, Eng SM, Teitelbaum SL, Paykin A, Levin B, Terry MB, Young TL, Wang LW, et al. 2002 Environmental toxins and breast cancer on Long Island. I. Polycyclic aromatic hydrocarbon DNA adducts. Cancer Epidemiology, Biomarkers and Prevention 11 677-685.

Gozgit JM, Nestor KM, Fasco MJ, Pentecost BT \& Arcaro KF 2004 Differential action of polycyclic aromatic hydrocarbons on endogenous estrogen-responsive genes and on a transfected estrogen-responsive reporter in MCF-7 cells. Toxicology and Applied Pharmacology 196 58-67. (https://doi.org/10.1016/j.taap.2003.12.003)

Hayakawa K, Bekki K, Yoshita M, Tachikawa C, Kameda T, Tang N, Toriba A \& Hosoi S 2011 Estrogenic/antiestrogenic activities of quinoid polycyclic aromatic hydrocarbons. Journal of Health Science $\mathbf{5 7}$ 274-280. (https://doi.org/10.1248/jhs.57.274)

Hirose T, Morito K, Kizu R, Toriba A, Hayakawa K, Ogawa S, Inoue S, Muramatsu M \& Masamune Y 2001 Estrogenic/antiestrogenic activities of benzo[a]pyrene monohydroxy derivatives. Journal of Health Science 47 552-558. (https://doi.org/10.1248/jhs.47.552)

Huang CY, Chen CA, Chen YL, Chiang CJ, Hsu TH, Lin MC, Lai MS, Chen CJ, You SL \& Cheng WF 2012 Nationwide surveillance in uterine cancer: survival analysis and the importance of birth cohort: 30-year population-based registry in Taiwan. PLoS ONE 7 e51372. (https://doi.org/10.1371/journal.pone.0051372)

Iannaccone PM, Fahl WE \& Stols L 1984 Reproductive toxicity associated with endometrial cell mediated metabolism of benzo[a]pyrene: a combined in vitro, in vivo approach. Carcinogenesis 5 1437-1442. (https://doi.org/10.1093/carcin/5.11.1437)

Koeber R, Niessner R \& Bayona JM 1997 Comparison of liquid chromatography-mass spectrometry interfaces for the analysis of polar metabolites of benz[a]pyrene. Fresenius' Journal of Analytical Chemistry 359 267-273. (https://doi.org/10.1007/s002160050571)

Korsh J, Shen A, Aliano K \& Davenport T 2015 Polycyclic aromatic hydrocarbons and breast cancer: a review of the literature. Breast Care 10 316-318. (https://doi.org/10.1159/000436956)

Kriek E, Van schooten FJ, Hillebrand MJ, Van Leeuwen FE, Den Engelse L, De Looff AJ \& Dijkmans AP 1993 DNA adducts as a measure of lung cancer risk in humans exposed to polycyclic aromatic hydrocarbons. Environmental Health Perspectives 99 71-75. (https://doi.org/10.1289/ ehp.939971)

Kummer V, Maskova J, Zraly Z, Neca J, Simeckova P, Vondracek J \& Machala M 2008 Estrogenic activity of environmental polycyclic aromatic hydrocarbons in uterus of immature Wistar rats. Toxicology Letters 180 212-221. (https://doi.org/10.1016/j.toxlet.2008.06.862)

Lam MM, Engwall M, Denison MS \& Larsson M 2018 Methylated polycyclic aromatic hydrocarbons and/or their metabolites are important contributors to the overall estrogenic activity of polycyclic aromatic hydrocarbon-contaminated soils. Environmental Toxicology and Chemistry 37 385-397. (https://doi.org/10.1002/etc.3958)

Liao XH, Lu DL, Wang N, Liu LY, Wang Y, Li YQ, Yan TB, Sun XG, Hu P \& Zhang TC 2014 Estrogen receptor alpha mediates proliferation of breast cancer MCF-7 cells via a p21/PCNA/E2F1-dependent pathway. FEBS Journal 281 927-942. (https://doi.org/10.1111/febs.12658) https://joe.bioscientifica.com https://doi.org/10.1530/JOE-19-0579 (c) 2020 Society for Endocrinology Published by Bioscientifica Ltd. Printed in Great Britain 
Littlefield BA, Gurpide E, Markiewicz L, Mckinley B \& Hochberg RB 1990 A simple and sensitive microtiter plate estrogen bioassay based on stimulation of alkaline phosphatase in Ishikawa cells: estrogenic action of delta 5 adrenal steroids. Endocrinology 127 2757-2762. (https://doi.org/10.1210/endo-127-6-2757)

Lu D, Harvey RG, Blair IA \& Penning TM 2011 Quantitation of benzo[a] pyrene metabolic profiles in human bronchoalveolar (H358) cells by stable isotope dilution liquid chromatography-atmospheric pressure chemical ionization mass spectrometry. Chemical Research in Toxicology 24 1905-1914. (https://doi.org/10.1021/tx2002614)

Morris JJ \& Seifter E 1992 The role of aromatic hydrocarbons in the genesis of breast cancer. Medical Hypotheses 38 177-184. (https://doi. org/10.1016/0306-9877(92)90090-y)

Penning TM 2014 Human aldo-keto reductases and the metabolic activation of polycyclic aromatic hydrocarbons. Chemical Research in Toxicology 27 1901-1917. (https://doi.org/10.1021/tx500298n)

Plagens-Rotman K, Zak E \& Pieta B 2016 Odds ratio analysis in women with endometrial cancer. Przeglad Menopauzalny 15 12-19. (https:// doi.org/10.5114/pm.2016.58767)

Plí̌ková M, Vondracek J, Vojtesek B, Kozubik A \& Machala M 2005 Deregulation of cell proliferation by polycyclic aromatic hydrocarbons in human breast carcinoma MCF-7 cells reflects both genotoxic and nongenotoxic events. Toxicological Sciences $\mathbf{8 3}$ 246-256. (https://doi.org/10.1093/toxsci/kfi040)

Poland A, Grover E \& Kende AS 1976 Stereospecific, high affinity binding of 2,3,7.8-tetrachlorodibenzo-p-dioxin by hepatic cytosol. Evidence that the binding species is receptor for induction of aryl hydrocarbon hydroxylase. Journal of Biological Chemistry 251 4936-4946.

Ran C, Xu D, Dai Q, Penning TM, Blair IA \& Harvey RG 2008 Synthesis of (13)C2-benzo[a]pyrene and its 7,8-dihydrodiol and 7,8-dione implicated as carcinogenic metabolites. Tetrahedron Letters 49 4531-4533. (https://doi.org/10.1016/j.tetlet.2008.05.033)

Rempel MA, Hester B, Deharo H, Hong H, Wang Y \& Schlenk D 2009 Effects of 17beta-estradiol, and its metabolite, 4-hydroxyestradiol on fertilization, embryo development and oxidative DNA damage in sand dollar (Dendraster excentricus) sperm. Science of the Total Environment 407 2209-2215. (https://doi.org/10.1016/j. scitotenv.2008.12.054)

Rodriguez AC, Blanchard Z, Maurer KA \& Gertz J 2019 Estrogen signaling in endometrial cancer: a key oncogenic pathway with several open questions. Hormones and Cancer 10 51-63. (https://doi.org/10.1007/ s12672-019-0358-9)

Rodríguez-Fragoso L, Melendez K, Hudson LG, Lauer FT \& Burchiel SW 2009 EGF-receptor phosphorylation and downstream signaling are activated by benzo[a]pyrene 3,6-quinone and benzo[a]pyrene 1,6-quinone in human mammary epithelial cells. Toxicology and Applied Pharmacology 235 321-328. (https://doi.org/10.1016/j.taap.2008.12.022)

Rundle A, Tang D, Hibshoosh H, Estabrook A, Schnabel F, Cao W, Grumet S \& Perera FP 2000 The relationship between genetic damage from polycyclic aromatic hydrocarbons in breast tissue and breast cancer. Carcinogenesis 21 1281-1289. (https://doi.org/10.1093/ carcin/21.7.1281)

Rutledge FN 1976 ARS presidential address: estrogen therapy: a causal role in endometrial cancer? American Journal of Roentgenology $\mathbf{1 2 7}$ 897-899. (https://doi.org/10.2214/ajr.127.6.897)

Sanderson JT, Slobbe L, Lansbergen GW, Safe S \& Van den Berg M 2001 2,3,7,8-Tetrachlorodibenzo-p-dioxin and diindolylmethanes differentially induce cytochrome P450 1A1, 1B1, and 19 in H295R human adrenocortical carcinoma cells. Toxicological Sciences 61 40-48. (https://doi.org/10.1093/toxsci/61.1.40)
Santodonato J 1997 Review of the estrogenic and antiestrogenic activity of polycyclic aromatic hydrocarbons: relationship to carcinogenicity. Chemosphere 34 835-848. (https://doi.org/10.1016/s00456535(97)00012-x)

Schaufler K, Haslmayer P, Jager W, Pec M \& Thalhammer T 2002 The environmental toxin 2,3,7,8-tetrachlorodibenzo-p-dioxin induces cytochrome P450 activity in high passage PC 3 and DU 145 human prostate cancer cell lines. International Journal of Molecular Medicine $\mathbf{9}$ 411-416. (https://doi.org/10.3892/ijmm.9.4.411)

Shen J, Liao Y, Hopper JL, Goldberg M, Santella RM \& terry MB 2017 Dependence of cancer risk from environmental exposures on underlying genetic susceptibility: an illustration with polycyclic aromatic hydrocarbons and breast cancer. British Journal of Cancer 116 1229-1233. (https://doi.org/10.1038/bjc.2017.81)

Shimada T \& Fujii-Kuriyama Y 2004 Metabolic activation of polycyclic aromatic hydrocarbons to carcinogens by cytochromes P450 1A1 and 1B1. Cancer Science 95 1-6. (https://doi.org/10.1111/j.1349-7006.2004. tb03162.x)

Siegel RL, Miller KD \& Jemal A 2019 Cancer statistics, 2019. CA: A Cancer Journal for Clinicians 69 7-34. (https://doi.org/10.3322/caac.21551)

Sjogren M, Ehrenberg L \& Rannug U 1996 Relevance of different biological assays in assessing initiating and promoting properties of polycyclic aromatic hydrocarbons with respect to carcinogenic potency. Mutation Research 358 97-112. (https://doi. org/10.1016/0027-5107(96)00175-3)

Song MK, Park YK \& Ryu JC 2013 Polycyclic aromatic hydrocarbon (PAH)-mediated upregulation of hepatic microRNA-181 family promotes cancer cell migration by targeting MAPK phosphatase-5, regulating the activation of $\mathrm{p} 38 \mathrm{MAPK}$. Toxicology and Applied Pharmacology 273 130-139. (https://doi.org/10.1016/j. taap.2013.08.016)

Soto am \& Sonnenschein C 1985 The role of estrogens on the proliferation of human breast tumor cells (MCF-7). Journal of Steroid Biochemistry 23 87-94. (https://doi.org/10.1016/0022-4731(85)90265-1)

Tu BB, Lin SL, Yan LY, Wang ZY, Sun QY \& Qiao J 2011 ER-alpha36, a novel variant of estrogen receptor alpha, is involved in EGFR-related carcinogenesis in endometrial cancer. American Journal of Obstetrics and Gynecology 205 227.e1-227.e6. (https://doi.org/10.1016/j. ajog.2011.04.015)

Wang Z, Wijewickrama GT, Peng KW, Dietz BM, Yuan L, Van Breemen RB, Bolton JL \& Thatcher GR 2009 Estrogen receptor \{alpha\} enhances the rate of oxidative DNA damage by targeting an equine estrogen catechol metabolite to the nucleus. Journal of Biological Chemistry $\mathbf{2 8 4}$ 8633-8642. (https://doi.org/10.1074/jbc.M807860200)

Wang Z, Chandrasena ER, Yuan Y, Peng KW, van Breemen RB, Thatcher GR \& Bolton JL 2010 Redox cycling of catechol estrogens generating apurinic/apyrimidinic sites and 8-oxo-deoxyguanosine via reactive oxygen species differentiates equine and human estrogens. Chemical Research in Toxicology 23 1365-1373. (https://doi. org/10.1021/tx1001282)

Weng MS, Chang JH, Hung WY, Yang YC \& Chien MH 2018 The interplay of reactive oxygen species and the epidermal growth factor receptor in tumor progression and drug resistance. Journal of Experimental and Clinical Cancer Research 37 61. (https://doi. org/10.1186/s13046-018-0728-0)

Zhou L, Cai B, Bao W, He YY, Chen XY, Yang YX, Liu XL \& Wan XP 2011 Crosstalk between estrogen receptor and mitogen-activated protein kinase signaling in the development and progression of endometrial cancer. International Journal of Gynecological Cancer 21 1357-1365. (https://doi.org/10.1097/IGC.0b013e3182216ac9) https://joe.bioscientifica.com https://doi.org/10.1530/JOE-19-0579
(C) 2020 Society for Endocrinology Published by Bioscientifica Ltd. Printed in Great Britain
Received in final form 3 July 2020

Accepted 26 August 2020

Accepted Manuscript published online 26 August 2020 